\title{
Effects of Dietary Fiber and Stevioside Mixture on Quality Attributes of Sausage and the Blood Properties of Rats
}

\author{
Jong-Ok Kang* and Sung-Moon Hong \\ Department of Animal Resources Science, Dankook University, Cheonan 330-714, Korea
}

\begin{abstract}
This study was conducted to examine the physiochemical characteristics (PC) of a sausage with added dietary fiber and stevioside mixture, as well as the blood properties (BP) of rats with feeding of the sausage. There were no significant differences between the control and the treatments in the PC; in case of treatments, as additive contents of dietary fiber (1-3\%) and stevioside $(0.05-1.5 \%)$, redness $\left(\mathrm{a}^{*}\right)$ gradually increased, but yellowness $\left(\mathrm{b}^{*}\right)$ rapidly decreased $(p<0.05)$. The $\mathrm{pH}$ level and water holding capacity (WHC) also tended to decrease. Thiobarbituric acid reactive substances (TBARS) were of little change. However, the texture of sensory evaluation and the adhesiveness of texture analysis had significantly low values $(p<0.05)$. BP, such as blood sugar, high density lipoprotein (HDL) cholesterol, low density lipoprotein (LDL) cholesterol and triglyceride (TG), did not increase and total cholesterol (TC) actually decreased $(p>0.05)$. However, body weights of rats increased with treatments. Overall, it is suggested that adding dietary fiber and stevioside mixture to sausages can moderately improve the redness, and also reduce the levels of sugar, cholesterol and neutral lipids in the blood without noticeably affecting the WHC, oxidant stability, appearance, and taste.
\end{abstract}

Key words: dietary fiber, stevioside, sausage quality, blood properties

\section{Introduction}

Food additives such as dietary fibers, isolated soy protein (ISP) and cereal flours have been regarded as binders or extenders in meat products. However, the additive substances are not only added for the purpose of safety, viscosity, water holding capacity, texture, and flavor of meat products, but also for coast, slicing characteristics and cooking loss prevention (Cofrades et al., 2000; Forrest et al., 1975). In addition, dietary fibers in particular inhibit absorption of fats and sugar, thus are known to prevent chronic diseases such as hypertension and diabetes. It has also been reported that dietary fibers are outstandingly effective in preventing constipation and colon cancer because they absorb moisture and facilitate defecation (Fernandez-Gines et al., 2004).

Recommended daily intake of total dietary fiber varies depending on age and gender, from country to country, and from institution to institution, with recommendations

\footnotetext{
*Corresponding author: Jong-Ok Kang, Department of Animal Resources Science, Dankook University, Cheonan 330-714, Korea. Tel: 82-41-550-3653, Fax: 82-41-550-3653, E-mail: jokang (a) dankook.ac.kr
}

of 25-31 $\mathrm{g}$ in Korea, 27-40 $\mathrm{g}$ by the World Health Organization (WHO, 1990) and 21-38 g in the United States. Daily dietary fiber intake is reportedly $19.8 \mathrm{~g}, 15.1 \mathrm{~g}$, and $15.4 \mathrm{~g}$ in Korea, the United States, and Japan, respectively, which amounts to only $50-60 \%$ of the recommended average daily intake.

Dietary fibers recently added to meat products like sausage include a vast array of vegetable materials including tomatoes, lemon albedo, oat bran, rye bran, wheat bran, corn bran, rice bran, kimchi powder (An et al., 2010), and animal materials such as chitosan (Kang and Lee, 2010). It is noteworthy that such extracts of dietary fiber contain antioxidant polyphenol compounds (Decker and Park, 2010; Lee et al., 2011).

On the other hand, sweeteners replacing sugar are also increasingly being used. Some sweeteners previously prohibit-ed due to their implied carcinogenicity have recently been proven by numerous studies to be unrelated to carcinogenicity (Geuns, 2003; Toyoda, 1997). Stevioside is extracted from leaves or stems of Stevia rebaudiana bertoni, a family of the wild chrysanthemum. Stevia rebaudiana bertoni is a steviol glucoside that is unfermented, indigestible, and an aglucone natural sweetener. As it is low calorie level, 1/90 of sugar (Park et al., 2010), 
and good stability, it is being widely used as a substitute sweetener in making bread and confectionary products, pickles, ice cream, marine products, soft drinks, chewing gum, and so forth (Geuns, 2002; In et al., 1997; Kim and Lee, 1996).

Though stevioside leaves a bitter aftertaste, a known drawback of the substance, its sweetness is estimated at 200-300 times that of sugar, with the glucose index (GI) coming close to 0 as compared to sugar estimated at 68 , crystallized fructose at 19 , xylitol at 8 and erythritol at 2. In addition, like dietary fibers, stevioside is discharged from the body without being decomposed or absorbed.

In the case of stevia (stevioside+rebaudioside), its antioxidant effects are known to be more than 20 times that of green tea (Kim et al., 2010), and much higher than trolox, a strong antioxidant (Tadhani et al., 2007). Thus, stevioside is expected to act as a substitute that can replace sugar and as an antioxidant

This study was conducted to examine the physiochemical characteristics of sausage with the addition of dietary fiber and stevioside mixture and their effects on the blood properties of rats.

\section{Materials and Methods}

\section{Sausage preparation and formulation}

The raw meat material used in this study consisted of hind legs and fat of refrigerated pork purchased from Daejon-Choongnam Pig Raising Cooperative, Choongnam province. The pork was kept refrigerated until used for the current project and the fat was kept frozen. A water soluble dietary fiber ( $\operatorname{starch} 85 \%$, Fibersol- $2^{\circledR}$ ) was purchased from Korea Matsutani Corp., and stevioside, 10 times sweeter than sugar, was purchased from Nambu Ham Company. For sodium nitrite, nitrite pickle salt (NPS) containing 5\% sodium nitrite was used. Based upon the recommendations incorporated in the methods for preparing sausage suggested by Kang and Lee (2008), cellulose casing with $3 \mathrm{~cm}$ of diameter was used. Smoking of the meat was performed at $50^{\circ} \mathrm{C}$ for $20 \mathrm{~min}$; while for heating the internal temperature was set at $63^{\circ} \mathrm{C}$ for 30 min and external temperature set at $72^{\circ} \mathrm{C}$. The main formulation of sausages is shown in Table 1. Phosphate $0.25 \%$, monosodium glutamate (MSG) $0.2 \%$, white pepper $0.2 \%$, vitamin $\mathrm{C} 0.05 \%$, nutmeg $0.05 \%$, coriander $0.05 \%$, ginger $0.03 \%$, cardamom $0.02 \%$ were also added as a common additive.
Table 1. Main formulations of sausage with added dietary fiber and stevioside

\begin{tabular}{lcccc}
\hline \hline \multirow{2}{*}{ Materials } & $\mathrm{C}^{1)}$ & $\mathrm{T}^{2)}$ & $\mathrm{T}^{3)}$ & $\mathrm{T}^{4)}$ \\
\cline { 2 - 5 } & $\%$ & $\%$ & $\%$ & $\%$ \\
\hline Meat & 60 & 60 & 60 & 60 \\
Fat & 20 & 20 & 20 & 20 \\
Ice/Water & 20 & 20 & 20 & 20 \\
Sub total & 100 & 100 & 100 & 100 \\
NPS & 0.2 & 0.2 & 0.2 & 0.2 \\
Sugar & 0.5 & 0 & 0 & 0 \\
Stevioside ${ }^{5)}$ & 0 & 0.05 & 0.1 & 0.15 \\
Dietary fiber & 0 & 1 & 2 & 3 \\
Salt & 1.2 & 1.2 & 1.2 & 1.2 \\
Sub total & 1.9 & 2.45 & 3.5 & 4.55 \\
\hline \multicolumn{1}{c}{ Total } & 101.9 & 102.5 & 103.5 & 104.55 \\
\hline
\end{tabular}

${ }^{1)}$ Control (dietary fiber (85\%) $0 \%+$ sugar $0.5 \%$ )

${ }^{2)}$ Treatment 1 (dietary fiber (85\%) $1 \%+$ stevioside $0.05 \%$ )

${ }^{3)}$ Treatment 2 (dietary fiber (85\%) 2\% + stevioside $0.1 \%$ )

${ }^{4)}$ Treatment 3 (dietary fiber (85\%) 3\% + stevioside $0.15 \%$ )

${ }^{5)}$ Stevioside, having a concentration 10 times greater than sugar, was purchased

\section{Experimental animals and blood sampling}

A total of 24 white male Sprague-Dawley (SD) rats, five-months-old, weighing 125-150 g were purchased from Koatech (Korea), and were allowed to adapt to their new environment for one week. When they weighed approximately $170 \mathrm{~g}$, they were sorted into four groups of six depending on weight according to a randomized complete block design. Rats were housed in the clean rack (New Biotech Co., Korea). Limited sausage (40 g/d) was supplied at the same time daily with free access to water for four weeks. Blood samples were drawn from the tail vein and heart, transferred to heparinized tubes, maintained in an ice bath for $20 \mathrm{~min}$, and then centrifuged at 3,000 rpm for $15 \mathrm{~min}$ to separate the plasma.

\section{Color evaluation (CIE L*, a*, b*)}

The sausages were cut, and lightness $\left(\mathrm{L}^{*}\right)$, redness $\left(\mathrm{a}^{*}\right)$, and yellowness $\left(b^{*}\right)$ of the surfaces measured with a Chroma Meter (Model CR-200b, Minolta, Japan) under a light source $\mathrm{C}$. For the standard color plate, the calibration plate of $\mathrm{L}^{*}=99.6, \mathrm{a}^{*}=0.3$, and $\mathrm{b}^{*}=1.7$ was used. Specimens were measured seven times repetitively focusing on six parts and the average was calculated.

\section{pH and water holding capacity (WHC)}

For sausage $\mathrm{pH}$ values, five measurements were made arbitrarily from the surface of the meat, with a HANNA instruments $^{\circledR}$, HI $8424 \mathrm{pH}$ meter and the average was calculated. For measurement of water holding capacity, a 
pressurized filter paper area method was employed in which sausage specimens weighing $2 \mathrm{~g}$ were placed on filter paper (Whatman No. 2) and pressurized at $10 \mathrm{~kg} /$ $\mathrm{cm}^{2}$ for a minute, after which the area of moisture spread on the filter paper was measured with a planimeter. The water holding capacity (\%) was calculated according to the following equation: water holding capacity $(\%)=(\mathrm{A}-$ B) $/ \mathrm{W} \times 100$, Here $\mathrm{A}$ represents the total area of the filter paper, B is the area of moisture formed by the sausage and $\mathrm{W}$ is the sample weight.

\section{Thiobarbituric Acid Reactive Substances (TBARS)}

For analysis of TBARS contents, a product of lipid or the measurement of the level of fat rancidity, a product of lipid peroxides decomposed in order to evaluate the level of fat rancidity, the method introduced in the previous paper (Kang and Lee, 2010) was employed. A solution of $20 \%$ trichloroacetic acid (TCA) $5 \mathrm{~mL}$ and N/100 thiobarbituric acid (TBA) $10 \mathrm{~mL}$ was added to $5 \mathrm{~g}$ of homogenized pork and heated at $100^{\circ} \mathrm{C}$ for $30 \mathrm{~min}$. After cooling, it was centrifuged at $3,000 \mathrm{rpm}$ for $10 \mathrm{~min}$. Isoamyl alcohol and $15 \mathrm{~mL}$ of pyrimidine 2:1 solution were added to the supernatant fluid and fully stirred. After two min, it was re-centrifuged at 3,000 rpm for $10 \mathrm{~min}$ and the supernatant fluid was filtered by filter paper (Whatman No.1). Light absorption of the filtered fluid was measured at 538 $\mathrm{nm}$. It was assumed that the higher the light absorption, the greater the oxidation of fat in the specimens.

\section{Texture analysis and sensory evaluations}

Previously refrigerated sausage was left at room temperature for $30 \mathrm{~min}$, then cut uniformly in sections measuring $3 \mathrm{~cm}$ wide and $1.3 \mathrm{~cm}$ long and pressurize at approximately $75 \%$ of the original size, twice with the aid of a $500 \mathrm{~N}$ load cell of a texture analyzer (TAXT-2/25, Stable Micro Systems, England). Springiness, cohesiveness, hardness, chewiness, gumminess, and adhesiveness, which are the primary characteristics of the sense of tissue, were measured 10 times repetitively for each specimen at a cross-head speed of $500 \mathrm{~mm} / \mathrm{min}$ and $100 \mathrm{~mm} /$ min and chart speed of $100 \mathrm{~mm} / \mathrm{min}$, and average values were calculated.

Sensory evaluations were conducted by 15 selected expert staff members. The sausage was graded with regard to outward appearance, color, tissue, and flavor by means of 5 point measuring scale. Grading was expressed by points as follows: $5=$ Excellent, $4=$ Good, $3=$ Average, $2=$ Poor, $1=$ Unsatisfactory, $0=$ Evaluation impossible. The sensory panels were separated by partitions in a quiet place for the sensory evaluation. After each sampling, the panels rinsed their mouths with purified water to cleanse the palate.

\section{Body weight gain and blood characteristics}

In rats, body weight gain was evaluated weekly with feed removed two hours prior to measurements. For blood sugar measurements, feed was withheld for $12 \mathrm{~h}$ on the $28^{\text {th }} \mathrm{d}$ of feeding, and fasting blood sugar levels measured by taking blood from the tail vein after which rats were fed sausage and blood sugar re-measured with Onetouch Ultra $^{\mathrm{TM}}$ (Lifescan, Korea). Specimens were transferred to Roksipja Corporation for analyzing triglyceride (TG), high density lipoprotein (HDL), low density lipoprotein (LDL) cholesterol, and total cholesterol (TC).

\section{Statistical analysis}

All data were analyzed using the general linear model (GLM) procedure of SAS (2008). Differences among treatment means were determined using the Duncan's multiple range test. A probability level of $p<0.05$ was considered to be statistically significant.

\section{Results and Discussion}

\section{Color evaluation}

The instrumental color evaluation of sausage was affected by adding dietary fiber and stevioside (Table 2). T2 and T3 had low $\mathrm{L}^{*}$ values and high a ${ }^{*}$ values compared to $\mathrm{C}$ and $\mathrm{T} 1$. However, $\mathrm{b}^{*}$ values gradually decreased according to the additive contents of mixture $(p<0.05)$. The addition of rice bran fiber (Choi et al., 2008a; Choi et al., 2008b), hazelnut shell (Turhan et al., 2005), walnut (Jimenez-Colmenero et al., 2003), and chitosan, which is an animal dietary fiber in ground pork and emulsified sausage showed low $\mathrm{L}^{*}$ values, which are similar results

Table 2. Instrumental color value of sausage with added dietary fiber and stevioside

\begin{tabular}{crrrrr}
\hline \multirow{2}{*}{ Parameters } & \multicolumn{5}{c}{ Treatments } \\
\cline { 2 - 6 } & $\mathrm{C}^{1)}$ & $\mathrm{T} 1^{2)}$ & $\mathrm{T} 2^{3)}$ & $\mathrm{T} 3^{4)}$ & $\mathrm{SEM}^{5)}$ \\
\hline $\mathrm{L}^{6)}$ & $73.65^{\mathrm{a}}$ & $73.57^{\mathrm{a}}$ & $71.69^{\mathrm{b}}$ & $71.97^{\mathrm{b}}$ & 0.18 \\
$\mathrm{a}^{7)}$ & $9.41^{\mathrm{c}}$ & $9.36^{\mathrm{c}}$ & $10.10^{\mathrm{b}}$ & $11.20^{\mathrm{a}}$ & 0.08 \\
$\mathrm{~b}^{8)}$ & $5.70^{\mathrm{c}}$ & $7.49^{\mathrm{a}}$ & $6.44^{\mathrm{b}}$ & $5.28^{\mathrm{d}}$ & 0.08 \\
\hline
\end{tabular}

\footnotetext{
${ }^{1-4)}$ Abbreviations are the same as Table 1.

${ }^{5)}$ Pooled standard error of the mean

${ }^{6}$ Lightness

${ }^{7}$ Redness

${ }^{8)}$ Yellowness

${ }^{\mathrm{a}-\mathrm{d}}$ Means in the same row with different superscripts differ $(p<0.05)$.
} 
to other report (Kang and Lee, 2008). However, the addition of wheat fiber and soy protein raised $\mathrm{L}^{*}$, and this change in $\mathrm{L}^{*}$ also affected values of $\mathrm{a}^{*}$ and $\mathrm{b}^{*}$ (Choi et al., 2007). The $a^{*}$ is highly significant because the color of meat products is intended to reproduce the color of fresh meat. Therefore, it was thought that T2 and T3 showed desirable colors since they had high levels of $\mathrm{a}^{*}(p<0.05)$ compared to C and T1 (Table 2). Choi et al. (2008a) demonstrated that when rice bran fiber, soy protein, and wheat fiber were added to ground pork and heated, there was no significant difference in redness compared to the control group. In the case of chitosan, $a^{*}$ values were found to increase at low concentrations $(0.2-0.3 \%)$, the low $\mathrm{pH}$ and low WHC, but they were decreased at $0.5 \%$, the high $\mathrm{pH}$ and high WHC, suggesting that color of meat products was related with the content of dietary fibers, $\mathrm{pH}$ and WHC (Kang and Lee, 2010; Yoon, 2001). The addition of wheat fiber and soy protein decreased $b^{*}$ values, but the addition of natural pigment ingredients such as chitosan, red beets, $\beta$-carotene (Kang and Lee, 2008), rice bran fiber and rye bran (Yilmaz, 2004) increased $b^{*}$ values. On the other hand, Yoon (2001) reported that stevioside had low $\mathrm{b}^{*}$ values. Accordingly, it was shown that the lowered $\mathrm{b}^{*}$ values found in T3 was largely attributable to dietary fiber and stevioside contents.

\section{pH and WHC}

The $\mathrm{pH}$ and $\mathrm{WHC}$ of $\mathrm{T} 2$ and $\mathrm{T} 3$ compared to $\mathrm{T} 1$ tended to decrease to $0.2 \%, 9.7 \%$ and $4.4 \%, 34.3 \%$, respectively. However, the $\mathrm{pH}$ and water holding capacity of $\mathrm{T} 1$ was only slightly higher than that of $\mathrm{C}$ (Table 3 ).

T3 had a significantly lower water holding capacity $(p<0.05)$ compared to T1 and T2. Yilmaz (2005) and Choi et al. (2007) asserted that the addition of dietary fiber raised $\mathrm{pH}$ and enhanced water holding capacity while lowering cooking losses (Aleson-Carbonell et al., 2005). Water holding capacity and $\mathrm{pH}$ are closely related to each other. Higher $\mathrm{pH}$ has high water holding capacity while isoelectric $\mathrm{pH}$ has low water holding capacity (Forrest et

Table 3. pH and water holding capacity (WHC) of sausage with added dietary fiber and and stevioside

\begin{tabular}{lrrrrr}
\hline \hline \multirow{2}{*}{ Parameters } & \multicolumn{5}{c}{ Treatments } \\
\cline { 2 - 6 } & \multicolumn{1}{c}{$\mathrm{C}^{\mathrm{l})}$} & \multicolumn{1}{c}{$\mathrm{T} 1^{2)}$} & \multicolumn{1}{c}{$\mathrm{T} 2^{3)}$} & \multicolumn{1}{c}{$\mathrm{T} 3^{4)}$} & $\mathrm{SEM}^{5)}$ \\
\hline $\mathrm{pH}$ & $5.31^{\mathrm{b}}$ & $5.67^{\mathrm{a}}$ & $5.66^{\mathrm{a}}$ & $5.12^{\mathrm{b}}$ & 0.06 \\
WHC (\%) & $66.06^{\mathrm{a}}$ & $66.57^{\mathrm{a}}$ & $63.65^{\mathrm{a}}$ & $43.79^{\mathrm{b}}$ & 1.15 \\
\hline
\end{tabular}

\footnotetext{
${ }^{1-5)}$ Abbreviations are the same as Table 1.

${ }^{a-b}$ Means in the same row with different superscripts differ $(p<$ $0.05)$.
}

al., 1975). However, T3 showed relatively lower WHC compared to $\mathrm{C}, \mathrm{T} 1$, and $\mathrm{T} 2(p<0.05)$. This result indicates that the excessive addition of dietary fiber causes a loss of moisture, thereby lowering water holding capacity (Choi et al., 2008a; Fernandez-Gines, 2004). Also, Yoon (2001) reported that confectionary products with stevioside tended to contain less moisture and increased in cooking losses.

\section{Thiobarbituric acid reactive substances (TBARS)}

Fig. 1 shows malondialdehyde (MDA) values in terms of TBARS to measure the level of oxidized fats. TBARS were not significantly different between control and treatment groups, which showed oxidation stability. Addition of grape dietary fiber contributed to oxidation stability as a result of the high antioxidant activity of superoxidedismutase (SOD) (Sayago et al., 2009; Zhang et al., 2009). Banana flour and fiber-rich powder displayed a high antioxidant activity to the point of showing a $90 \%$ decrease of 2.2-diphenyl-1-picrylhydrazyl (DPPH) (RodriquezAmbriz et al., 2008). When it comes to dietary fibers, fruits and vegetables contain $5.38 \mathrm{mg} / \mathrm{g}, 2.87 \mathrm{mg} / \mathrm{g}$ of polyphenol, respectively (Saura-Calixto and Goni, 2006). Analyses of the total of 75 polyphenol ingredients, the antioxidant compounds contained in a wide variety of herbs, showed that stevia topped the list (Yamamoto et al., 2001) having 20 times as much antioxidant capacity as green tea (Kim et al., 2010), although the results could be different depending on the method of extraction. Accordingly, the level of antioxidant activity seems to originate more from the ingredients and contents of polyphenols rather than dietary fiber itself.

\section{Texture analysis and sensory evaluations}

The springiness, cohesiveness, hardness, chewiness, gumminess, and adhesiveness of sausages with added dietary

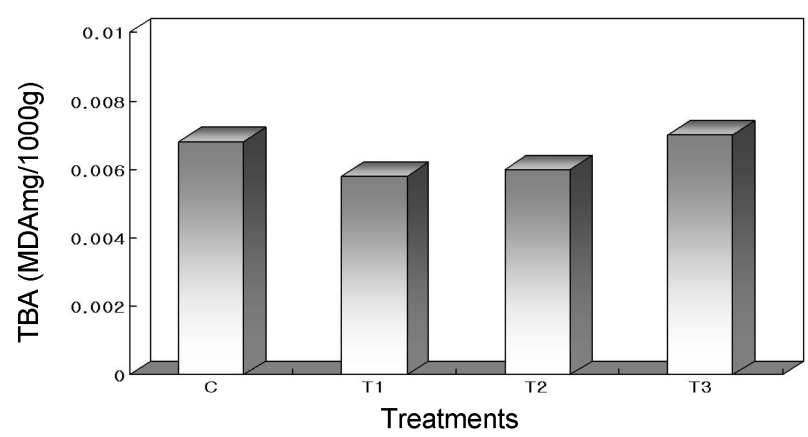

Fig. 1. TBARS of sausages with added dietary fiber and stevioside. Abbreviations are the same as Table 1. 
fiber and stevioside are shown in Table 4. No statistical difference was found among the treatment groups $(p>$ 0.05 ). However, the treatment groups showed higher values across all items except springiness $(p<0.05)$ compared to the control. It was a similar results that the addition of isolated soy protein, wheat fiber, and so forth to meat products raised hardness, gumminess, and chewiness (Choi et al., 2007; Lee et al., 2003).

Also, it is known that the addition of dietary fiber or starch raises hardness to a certain level (Choi et al., 2008b; Hughes et al., 1998) because tissue characteristics of meat products are determined by emulsification, water holding capacity, gel formation capacity, and adhesiveness between particles (Mittal and Usborne, 1985). On the other hand, the addition of stevioside to confectionary products caused lower hardness than when sugar was added (Yoon, 2001). The addition of oatmeal and tofu to sausage also caused lower hardness levels (Yang et al., 2007).

The sensory evaluations of appearance, color, texture, and flavor of sausage with added dietary fiber and stevioside are shown in Table 5. No significant differences of appearance and flavor was found between the control group and treatment groups in terms of appearance, and flavor, whereas treatments scored significantly lower in texture which seems to be associated with hardness of tissue. However, T1 scored high in appearance, color, and flavor. Choi et al. (2008b) and other investigators reported that groups with dietary fiber from rice hulls (53.27\%) $2 \%$, mugwort powder (\% not shown) $2 \%$ (Han et al., 2006), and hazelnut fiber (59.19\%) 1-2\% (Thurhan et al., 2005) added, scored high. Conversely the group with lemon albedo fiber (cooked 22\%, raw 30\%) 5\% added (Fernandez-Gines et al., 2004) was similar to the conventional sausage. These results indicate that adding an optimum level of dietary fiber is important. It was reported that addition of glutinous dietary fiber to meat products

Table 4. Texture analysis of sausage with added dietary fiber and stevioside

\begin{tabular}{lrrrrr}
\hline \hline \multirow{2}{*}{ Parameters } & \multicolumn{5}{c}{ Treatments } \\
\cline { 2 - 6 } & \multicolumn{1}{c}{$\mathrm{C}^{\mathrm{l})}$} & \multicolumn{1}{c}{$\mathrm{T} 1^{2)}$} & \multicolumn{1}{c}{$\mathrm{T} 2^{3)}$} & \multicolumn{1}{c}{$\mathrm{T} 3^{4)}$} & $\mathrm{SEM}^{5)}$ \\
\hline Springiness (mm) & $0.97^{\mathrm{a}}$ & $0.93^{\mathrm{b}}$ & $0.96^{\mathrm{ab}}$ & $0.94^{\mathrm{ab}}$ & 0.01 \\
Cohesiveness (\%) & $0.59^{\mathrm{a}}$ & $0.60^{\mathrm{a}}$ & $0.68^{\mathrm{a}}$ & $0.60^{\mathrm{a}}$ & 0.04 \\
Chewiness (g) & $741.20^{\mathrm{a}}$ & $806.74^{\mathrm{a}}$ & $844.34^{\mathrm{a}}$ & $821.14^{\mathrm{a}}$ & 42.03 \\
Hardness (g) & $1310.10^{\mathrm{a}}$ & $1446.28^{\mathrm{a}}$ & $1471.95^{\mathrm{a}}$ & $1451.98^{\mathrm{a}}$ & 69.77 \\
Gumminess (g) & $767.04^{\mathrm{a}}$ & $869.42^{\mathrm{a}}$ & $882.61^{\mathrm{a}}$ & $873.45^{\mathrm{a}}$ & 42.32 \\
Adhesiveness (g) & $-40.23^{\mathrm{b}}$ & $-19.09^{\mathrm{a}}$ & $-29.06^{\mathrm{ab}}$ & $-33.33^{\mathrm{ab}}$ & 6.03 \\
\hline
\end{tabular}

\footnotetext{
${ }^{1-5)}$ Abbreviations are the same as Table 1.

${ }^{\mathrm{a}-\mathrm{b}}$ Means in the same row with different superscripts differ $(p<0.05)$.
}

increased sensory features of the products in physiochemical factors by raising glutinousness (Lee, 2001).

\section{Body weight gains and blood properties}

T2 showed a significant difference in increasing rat body weights compared to C (Table 6). However, no significant difference was found among the treatment groups. Increases in body weights found in the treatment groups when compared to those in the control group appeared to be similar to the effects of adding chitosan (Kang and Lee, 2010), which causes weight to increase, independent of increases in dietary fiber. Park and Kwon (1997) also reported increases in weights of white rats were shown in the group with lignin and cellulose addition. However, the epidemiological survey on adolescents past the growth period and adults indicated that intake of dietary fiber in relation to obesity reduced weight as a rule and was effective in preventing type II-diabetes and cardiovascular diseases (Slavin, 2006).

In our study, significant difference was found between the control and T1 with regard to blood sugar of rats (Table 6) but increased addition of dietary fiber and stevioside did not increase blood sugar. Supposedly, this result is attributable to both the fact that dietary fiber lowers blood sugar by delaying absorption of sugar and also due to very low GI and antioxidant effects of stevioside used as a sugar substitute. It has been known that addition of antioxidant substances containing polyphe-

Table 5. Sensory evaluation of sausage with added dietary fiber and stevioside

\begin{tabular}{lccccc}
\hline \multirow{2}{*}{ Parameters } & \multicolumn{5}{c}{ Treatments } \\
\cline { 2 - 6 } & $\mathrm{C}^{1)}$ & $\mathrm{T}^{2)}$ & $\mathrm{T}^{3)}$ & $\mathrm{T}^{4)}$ & $\mathrm{SEM}^{5)}$ \\
\hline Appearance & $2.63^{\mathrm{a}}$ & $3.20^{\mathrm{a}}$ & $2.65^{\mathrm{a}}$ & $3.34^{\mathrm{a}}$ & 0.12 \\
Color & $3.13^{\mathrm{a}}$ & $3.14^{\mathrm{a}}$ & $2.75^{\mathrm{b}}$ & $2.94^{\mathrm{b}}$ & 0.14 \\
Texture & $2.83^{\mathrm{a}}$ & $2.51^{\mathrm{b}}$ & $2.61^{\mathrm{ab}}$ & $2.65^{\mathrm{ab}}$ & 0.15 \\
Flavor & $1.98^{\mathrm{a}}$ & $2.45^{\mathrm{a}}$ & $2.43^{\mathrm{a}}$ & $2.34^{\mathrm{a}}$ & 0.13 \\
\hline
\end{tabular}

1)-5) Abbreviations are the same as Table 1.

${ }^{a-b}$ Means in the same row with different superscripts differ $(p<0.05)$.

Table 6. Body weight gain (BWG) and blood glucose level (BGL) of rat fed sausage with added dietary fiber and stevioside

\begin{tabular}{cccccr}
\hline \hline \multirow{2}{*}{ Parameter } & \multicolumn{5}{c}{ Treatments } \\
\cline { 2 - 6 } & $\mathrm{C}^{\mathrm{l})}$ & $\mathrm{T}^{2)}$ & $\mathrm{T}^{3)}$ & $\mathrm{T}^{4)}$ & $\mathrm{SEM}^{5)}$ \\
\hline BWG(g) & $38.00^{\mathrm{b}}$ & $47.50^{\mathrm{ab}}$ & $61.50^{\mathrm{a}}$ & $48.67^{\mathrm{ab}}$ & 5.98 \\
\hline BGL Pre-feeding (mg/dL) & $91.17^{\mathrm{a}}$ & $100.00^{\mathrm{a}}$ & $85.00^{\mathrm{a}}$ & $98.00^{\mathrm{a}}$ & 8.90 \\
Post-feeding (mg/dL) $139.67^{\mathrm{b}}$ & $138.67^{\mathrm{a}}$ & $134.83^{\mathrm{ab}}$ & $136.33^{\mathrm{ab}}$ & 11.15 \\
\hline $\begin{array}{l}{ }^{1-5)} \text { Abbreviations are the same as Table 1. } \\
\text { a-b Means in the same row with different superscripts differ }(p<0.05) .\end{array}$
\end{tabular}


Table 7. Effect of feeding sausage with added dietary fiber and stevioside on rat blood plasma parameters

\begin{tabular}{lrrrrr}
\hline \hline \multirow{2}{*}{$\begin{array}{c}\text { Parameters } \\
(\mathrm{mg} / \mathrm{dL})\end{array}$} & \multicolumn{5}{c}{ Treatments } \\
\cline { 2 - 6 } & \multicolumn{1}{c}{$\mathrm{C} 1^{2)}$} & \multicolumn{1}{c}{$\mathrm{T} 2^{3)}$} & \multicolumn{1}{c}{$\mathrm{T} 3^{4)}$} & $\mathrm{SEM}^{5)}$ \\
\hline $\mathrm{TC}^{6)}$ & $97.00^{\mathrm{a}}$ & $87.17^{\mathrm{ab}}$ & $84.50^{\mathrm{ab}}$ & $83.83^{\mathrm{b}}$ & 4.05 \\
$\mathrm{HDL}^{7)}$ & $29.50^{\mathrm{a}}$ & $28.67^{\mathrm{a}}$ & $28.17^{\mathrm{a}}$ & $27.17^{\mathrm{a}}$ & 1.26 \\
$\mathrm{LDL}^{8)}$ & $17.67^{\mathrm{a}}$ & $15.00^{\mathrm{a}}$ & $14.33^{\mathrm{a}}$ & $15.33^{\mathrm{a}}$ & 1.42 \\
$\mathrm{TG}^{9)}$ & $146.50^{\mathrm{a}}$ & $103.50^{\mathrm{a}}$ & $116.33^{\mathrm{a}}$ & $104.67^{\mathrm{a}}$ & 8.02 \\
\hline
\end{tabular}

${ }^{1-5)}$ Abbreviations are the same as Table 1 .

${ }^{6)}$ Total cholesterol

${ }^{7)}$ High density lipoprotein

${ }^{8)}$ Low density lipoprotein

${ }^{9)}$ Triglyceride

${ }^{a-b}$ Means in same row with different superscripts differ $(p<0.05)$.

nols such as Eriobotrya japonica seed extracts and Opuntia ficus indica extracts were also effective to lowering blood sugar (Yoon and Son, 2009), and that the blood sugar lowering effects of giant embryonic rice, 2-3 times as large as embryos of rice, are largely attributable to dietary fiber and antioxidant ingredients (Lee et al., 2006).

TC levels (Table 7) tended to decrease in the order of increased concentrations of the materials in the treatment groups compared to $\mathrm{C}(p>0.05)$. However, $\mathrm{C}$ and $\mathrm{T} 3$ showed a significant difference $(p<0.05)$. Except for HDL, LDL and TG also decreased in the treatment groups compared to C. However, there was no significant difference. Poller (1970) reported that an increased incidence of cardiovascular disease was attributable to increased intake of animal fats and reduced intake of dietary fiber, and Lee et al. (2011) reported that the contents of TG and TC in the semen increased as a result of intake of high fat-cholesterol diets, whereas as a result of the addition of ground ramie leaves containing dietary fiber (39.7\%) and polyphenol compounds, there was a concentration-dependent decrease, and contrary to the fact that LDL decreased significantly, HDL, allegedly a helpful cholesterol increased.

In conclusion, addition of dietary fiber and stevioside is expected to increase redness, control the rat's blood sugar level, and decrease cholesterol and neutral fats without noticeably affecting the appearances and taste of regular sausages in the market. Also, the antioxidant effects of $\mathrm{T} 1$ and $\mathrm{T} 2$ in particular are thought to be effects of dietary fiber and stevioside. Since excessive addition of the two substances could decrease water holding capacity, it is necessary to maintain the appropriate levels of addition.

\section{Acknowledgement}

The present research was conducted with research funds from Dankook University in 2009.

\section{References}

1. Aleson-Carbonell, L., Fernandez-Lopez, J., Perez-Alvarez, J. A., and Kuri, V. (2005) Characteristics of beef burger as influenced by various types of lemon albedo. Innovative Food Sci. Emerging Technol. 6, 247-255.

2. An, K. I., Choi, J. H., Choi, Y. S., Han, D. J., Kim, H. Y., Lee, M. I., Kim, S. Y., Kim, T. H., and Kim, C. J. (2010) Effects of Kimchi powder on quality characteristics of semi-dried pork jerky. Korean J. Food Sci. Ani. Resour. 30, 198-205.

3. Choi, Y. S., Choi, J. H., Han, D. J., Kim, H. Y., Lee, M. A., Kim, H. W., Jeong, J. Y., Paik, H. D., and Kim. C. J. (2008a) Effect of adding levels of rice bran fiber on the quality characteristics of ground pork meat product. J. Food Sci. 28. 319326.

4. Choi, Y. S., Jeong, J. Y., Choi, J. H., Han, D. J., Kim, H. Y., Lee, M. A., Kim, H. W., Paik, H. D., and Kim, C. J. (2008b) Effects of dietary fiber from rice bran on the quality characteristics of emulsion-type sausages. Korean J. Food Sci. Ani. Resour. 28, 14-20.

5. Choi, Y. S., Lee, M. A., Jeong, J. Y., Choi, J. H., Han, D. J., Kim, H. Y., Lee, E. S., and Kim, C. J. (2007) Effects of wheat fiber on the quality of meat batter. J. Food Sci. 27, 22-28.

6. Cofrades, S., Guerra, A., Carballo, J., Fernandez-Martin, F., and Jimenez-Colmenero, F. (2000) Plasma protein and soy fiber content effect on bologna sausage properties as influenced by fat level. J. Food Sci. 65, 281-287.

7. Decker, E. A. and Park, Y. H. (2010) Healthier meat products as functional foods. Meat Sci. 86, 49-55.

8. Fernandez-Gines, J. M., Fernandez-Lopez, J., Sayas-Barbera, E., Senara, E., and Perez-Álvarez, J. A. (2004) Lemon albedo as a new source of dietary fiber: Application to bologna sausage. Meat Sci. 67, 7-13.

9. Forrest, J. C., Aberle, E. D., Hedrick, H. B., Judge, M. D., and Merkel, R. A. (1975) Principles of meat processing. Principles of meat science. W. H. Freeman and Company. San Francisco, CA. pp. 190-226.

10. Geuns, Jan M. C. (2002) Safety evaluation of Stevia and stevioside. Studies in natural products. Chemistry 27, part 8. Elsevier.

11. Geuns, Jan M. C. (2003) Molecules of interest stevioside. Phytochem. 64, 913-921.

12. Han, K. H., Choi, I. S., and Lee, C. H. (2006) The physicochemical and storage characteristics of sausage added mugwort powder. Korean J. Food Sci, Ani. Resour. 26, 356-361.

13. Hughes, E., Mullen, A. M., and Troy, D. J. (1998) Effects of fat level, tapioca and whey protein on frankfurters formulated with $5 \%$ and $12 \%$ fat. Meat Sci. 48, 169-180.

14. In, M. J., Chae, H. J., and Kim, M. H. (1997) Continuous production of transglucosylated steviosides using immobi- 
lized cyclodextrin glucanotransferase. Korean J. Food Sci. Technol. 29, 969-973.

15. Jenkins, D. J. A., Wolever, T. M. S., Taylor, R. H., Barker, H., Fielden, H., Baldwin, J. M., Bowing, A. C., Newman, H. C., Jenkins, A. L., and Goff, D. V. (1981) Glycemic index of foods: a physiological basis for carbohydrate exchange. Am. J. Clin. Nutr. 34, 362-366.

16. Jimenez-Colmenero, F., Serrano, A., Ayo, J., Solas, M. T., Cofrades, S., and Carballo, J. (2003) Physicochemical and sensory characteristics of restructured beef steak with added walnuts. Meat Sci. 65, 1391-1397.

17. Kang, J. O. and Lee, S. G. (2010) Effects of chitosan on reduction of sodium lactate in sodium nitrite-reduced sausages. Korean J. Food Sci. Technol. 52, 43-50.

18. Kang, J. O. and Lee, S. G. (2008) Effects of pigment of Opuntia ficus and sodium lactate on nitrite-reduced sausages. Korean J. Food Sci. Tech. 50, 551-560.

19. Kim, H. I. and Lee, B, M. (1996) Stevioside, a natural sweetener. J. Food Hyg. Safety 11, 323-327.

20. Kim, J. H., Sung, N. Y., Kwon, S. K., Jung, P. M., Choi, J. I., Yoon, Y. H., Song, B. S., Yoon, T. Y., Kee, H. J., and Lee, J. W. (2010) Antioxidant activity of stevia leaf extracts prepared by various extraction methods. J. Korean Soc. Food Sci. Nutr. 39, 313-318.

21. Lee, J. J., Park, M. R., Kim, A. R., and Lee, M. Y. (2011) Effects of ramie leaves on improvement of lipid metabolism and anti-obesity effect in rats fed a high fat/high cholesterol diet. Korean J. Food Sci. Technol. 43, 83-90.

22. Lee, J. R., Jung, J. D., Lee, J. I., Song, Y. M., Jin, S. K., Kim, I. S., Kim, H. Y., and Lee, J. H. (2003) The effects of emulsion type sausages containing mulberry leaf and persimmon leaf powder in lipid oxidation, nitrite, VBN and fatty acid composition. Korean J. Food Sci. Technol. 23, 1-8.

23. Lee, Y. R., Nam, S. H., and Kang, M. Y. (2006) Hypoglycemic effect of the giant embryonic rice supplementation on Streptozotocin-induced diabetic rats. Korean J. Food Sci. Technol. 38, 427-431.

24. Lee, Y. T. (2001) Dietary fiber composition and viscosity of extracts from domestic barley, wheat, oat, and rye. Korean $J$. Food. Nutr. 14, 233-238.

25. Mittal, G. S. and Usborne, W. R. (1985) Meat emulsion extender. Food Technol. 39, 121-130.

26. Park, J. U., Kee, H. J., and Cha, Y. S. (2010) Effect of Stevia rebaudiana bertoni leaf extract on antiobesity in C57BL/6J mice. Korean J. Food Sci. Technol. 42, 586-592.

27. Park, Y, J. and Kwon, K. H. (1997) Effects of dietary fiber and fat sources on lipid contents of serum and tissues in rats fed cholesterol diet. J. East Asian Dietary Life 7, 411-418.

28. Poller, L. (1970) Fiber and diabetes. Lancet 24, 434-435.

29. Rodriquez-Ambriz, S. L., Islas-Hernandez, J. J., Agama-
Acevedo, E., Tovar, J., and Bello-Perz, L. A. (2008) Characterization of a fibre-rich powder prepared by liquefaction of unripe banana flour. Food Chem. 107, 1515-1521.

30. SAS (2008) SAS/STAT Software for PC. Release 9.2, SAS Institute Inc., Cary, NC, USA.

31. Saura-Calixto, F. and Goni, I. (2006) Antioxidant capacity of the spanish mediterranean diet. Food Chem. 94, 442-447.

32. Sayago-Ayerdi, S. G., Brense, A., and Goni, I. (2009) Effect of grape antioxidant dietary fiber on the lipid oxidation of low and cooked chicken hamburgers. LWT-Food Sci. Technol. 42, 971-976.

33. Slavin, J. L. (2006) Dietary fiber and body weight. Nutrition 21, 411-418.

34. Tadhani, M. B., Patela, V. H., and Subahash, R. (2007) In vitro antioxidant activities of stevia rebaudiana leaves and callus. J. Food Comp. Anal. 20, 32-329.

35. Toyoda, K., Matsui, H., Shoda, K., Uneyama, C., Takada, K., and Takahashi, M. (1997) Assessment of the carcinogenicity of stevioside in F344 rats. Food Chem. Toxicol. 35, 597-603.

36. Turhan, S., Sagir, I., and Ustun, N. S. (2005) Utilization of hazelnut pellicle in low-fat beef burger. Meat Sci. 71, 312-316.

37. World Health Organization (1990) Diet, nutrition and the prevention of chronical disease. WHO Technical Report Series No. 797, Geneva.

38. Yang, H. S., Choi, S. G., Jeon, J. T., Park, G. B., and Joo, S. T. (2007) Textural and sensory properties of low fat pork sausages with added hydrated oatmeal and tofu as texture-modifying agents. Meat Sci. 75, 283-289.

39. Yamamoto, N., Mizue, S., Sano, K., Takano, N., Miyamoto, A., Ueno, Y., Kudo, K., and Michizuki, S. (2001) Characterization of food composition and functionality of herbs cultivated in Oita. Report. 36, Oita, Japan. 144-149.

40. Yilmaz, I. (2004) Effects of rye bran addition on fatty acid composition and quality characteristics of low-fat meatball. Meat Sci. 67, 245-249.

41. Yilmaz, I. (2005) Physicochemical and sensory characteristics of low fat meatballs with added wheat bran. J. Food Eng. 69, 369-373.

42. Yoon, J. A., and Son, Y. S. (2009) Effect of opuntia ficusindica complexes B (OCB) on blood glucose and lipid metabolism in streptozotocin-induced diabetic rats. Korean J. Nutr. 22, 48-56.

43. Yoon, K. H. (2001) Characteristics of pound cakes containing stevioside and maltitol. Korean J. Food Nutr. 14, 391-396.

44. Zhang, X. H., Choi, S. K., and Seo, J. S. (2009) Effect of dietary grape pomace on lipid oxidation and related enzyme activities in rats fed high fat diet. Korean J. Nutr. 42, 415-422.

$\overline{\text { (Received 2011.12.19/Revised 2012.1.11/Accepted 2012.3.14) }}$ 